\title{
Prevalence of dirofilariasis in cats in the Kars province, Turkey")
}

\author{
EKIN EMRE ERKILIÇ, NERIMAN MOR*, ALI HAYDAR KIRMIZIGÜL
}

\begin{abstract}
Department of Internal Medicine, Faculty of Veterinary Medicine, University of Kafkas, 36300, Kars, Turkey *Department of Parasitology, Faculty of Medicine,University of Kafkas, 36300, Kars, Turkey
\end{abstract}

Erkılıç E. E., Mor N., Kırmızıgül A. H. Prevalence of dirofilariasis in cats in the Kars province, Turkey

Summary

Dirofilariasis is a vector-borne disease which is zoonotic. The aim of this study was to determine the seroprevalence of dirofilariasis in indoor cats with outdoor access in the centre and districts of the Kars province. Blood samples were collected from a total of 150 cats, including 71 males and 79 females. The localities selected for sampling were the centre of the Kars province $(n=78)$, and the districts Sarıkamış $(n=30)$, Arpaçay $(n=24)$ and Selim $(n=18)$. Dirofilariasis seropositivity was $29.5 \%$ in the centre of the Kars province, $16.7 \%$ in Sarıkamış, 8.3\% in Arpaçay and 5.6\% in Selim. The seropositivity rate of the male cats (18.3\% - 13/71) was lower than that of the females $(22.8 \%-18 / 79)$. The assessment of seropositivity for the different age groups showed that seropositivity was $22 \%$ in cats aged $1-2$ years, $21.4 \%$ in cats aged $3-4$ years, and $18.2 \%$ in cats aged 5 years and older. Statistical analyses demonstrated that the differences observed for sex and age were insignificant $(P>0.05)$. The overall seropositivity rate was found to be $20.7 \%$. This seroprevalence determined for dirofilariasis in cats in the Kars region suggests that prophylactic measures need to be taken against the disease in this area.

Keywords: cat, dirofilariasis, Kars, Turkey

Dirofilariasis is a zoonotic vector-borne disease, threatening for public health and showing an increased distribution worldwide (1). The highest number of cases are observed particularly in tropical and subtropical regions (4). The prevalence of dirofilariasis tends to be rather high in river valleys and humid regions. This is due to such locations being favourable for the vectors of the disease (26). The two main causative agents of the disease are Dirofilaria immitis and Dirofilaria repens. Of these agents, $D$. immitis causes heartworm disease, and $D$. repens causes subcutaneous filariosis in dogs and cats. These agents infect both wild and domestic carnivores in Europe, Asia and Africa (14). Both $D$. immitis and $D$. repens are transmitted by mosquitoes, and those belonging to the genera Culex, Aedes and Anopheles are the main vectors of the disease $(28,30)$. The length of the adult female parasites may reach $17 \mathrm{~cm}$ in $D$. repens and may be up to $30 \mathrm{~cm}$ in D. immitis. The life cycles of both Dirofilaria species are similar. However, D. repens differs in that the adult parasites of this species are mainly found in subcutaneous tissues (13). The definitive (final) hosts of

This research was supported by Kafkas University Scientific Research Projects Commission.
D. repens are dogs and other carnivores. Humans serve as an incidental host for this parasite. In regions where the disease is endemic, the prevalence in cats is lower than that in dogs (3). The prevalence of $D$. immitis in cats is affected by several factors. The population density of the vectors, the mosquito species found in a particular region, and dirofilariasis having an endemic course in dogs in a region are risk factors (19). Generally, cats have a natural resistance to infection with $D$. immitis $(6,12)$. Although cats infected with this species develop pathological changes in the respiratory system, the disease is mostly asymptomatic in these animals (12). In infected cats, clinical signs may be present such as, acute death, intermittent dyspnoea, chronic cough, and vomiting. The migration of the parasitic larvae to the brain may cause neurological symptoms such as blindness, syncope, collapse and vestibular signs (20).

Dirofilariasis has been reported in dogs in several studies from Turkey. To the authors' knowledge there is no report in the literature available on this zoonotic disease in cats. This study was aimed at determining the seroprevalence of dirofilariasis in indoor cats with outdoor access in the Kars region. 


\section{Material and methods}

This study was conducted after receiving approval from Kafkas University Animal Experiments Local Ethics Committee (KAÜ-HADYEK/ 2016-074).

Study area. The study was carried out in the Kars province, which is located in northeast Anatolia and has a cold climate (11). The centre of the Kars province and the districts Sarıkamıs, Arpaçay and Selim were selected as the sampling locations. The average temperatures of Kars center, Arpaçay, Selim and Sarıkamıs for the last three years (20162018) are $6.21^{\circ} \mathrm{C}, 6.66^{\circ} \mathrm{C}, 5.98^{\circ} \mathrm{C}$ and $5.07^{\circ} \mathrm{C}$, respectively. The average rainfall was $37.83 \mathrm{~kg} / \mathrm{m}^{2}, 17.16 \mathrm{~kg} / \mathrm{m}^{2}, 34.48$ $\mathrm{kg} / \mathrm{m}^{2}$ and $33.38 \mathrm{~kg} / \mathrm{m}^{2}$ respectively. The average relative humidity was $63.65 \%, 68.08 \%, 70.22 \%$ and $68.25 \%$ (18).

Animals. A total of 150 cats of varying age, including 71 males and 79 females, indoor cats with outdoor access, constituted the study material.

Collection of blood samples. Of the blood samples collected, 78 belonged to the centre of the Kars province, 30 to Sarıkamış, 24 to Arpaçay, and 18 to Selim. Of the animals included in the study, 50 were 1-2 years old, 56 were 3-4 years old, and 44 were aged 5 years or older. Five-mL blood samples were taken from the radial vein of each animal for analyses. The blood samples were centrifuged at $3000 \mathrm{rpm}$ for $10 \mathrm{~min}$ for the extraction of sera. The serum samples were transferred into eppendorf tubes and stored at $-20^{\circ} \mathrm{C}$ until being analysed. Measurements were performed using a commercial Enzyme-Linked Immunosorbent Assay (ELISA) kit (MyBiosource ${ }^{\circledR}$ ).

Statistical analysis. The results were performed by using chi-square analysis in SPSS 20.0 statistical software package. Values of $\mathrm{P}<0.05$ were considered to be statistically significant.

\section{Results and discussion}

The results of the present study demonstrated that dirofilariasis seropositivity was $29.5 \%(23 / 78)$ in the centre of the Kars province, $16.7 \%$ (5/30) in Sarıkamıs, $5.6 \%(1 / 18)$ in Selim, and 8.3\% (2/24) in Arpaçay. The collective evaluation of all sampling localities revealed a mean seropositivity rate of $20.7 \%(31 / 150)$ in cats in the Kars region (Tab. 1). The highest seropositivity rate was detected in the blood samples belonging to the centre of the Kars province. Analyses revealed that the differences observed between the sampling localities were statistically significant $(\mathrm{P}<0.05)$.

Analysis results showed that out of the 79 female cats $18(22.8 \%)$ and out of the 71 male cats $13(18.3 \%)$ were seropositive for dirofilariasis (Tab. 2). Although the seropositivity rate of the female cats was higher than that of the male cats, the difference observed between the two sexes was statistically insignificant $(\mathrm{P}>0.05)$.

Of the animals included in the present study, 50 were 1-2 years old, 56 were $3-4$ years old, and 44 were aged 5 years and older. The seropositivity rates detected in the groups aged 1-2 years, 3-4 years, and 5 years and
Tab. 2. Seropositivity rates for dirofilariasis in male and female cats

\begin{tabular}{|l|c|c|c|c|}
\hline \multicolumn{1}{|c|}{ Sex } & $\begin{array}{c}\text { Number of } \\
\text { animals }\end{array}$ & \multicolumn{2}{|c|}{$\begin{array}{c}\text { In-group } \\
\text { percentage } \\
(+)\end{array}$} & $\begin{array}{c}\text { Percentile share in total number } \\
\text { of seropositive animals }(\mathrm{n}=31)\end{array}$ \\
\hline Female & 79 & 18 & 22.8 & $(\%)$ \\
\hline Male & 71 & 13 & 18.3 & 58.1 \\
Total & 150 & 31 & 20.7 & 41.9 \\
\hline
\end{tabular}

Tab. 3. Seropositivity rates for dirofilariasis in different age groups of cats

\begin{tabular}{|l|c|c|c|c|}
\hline $\begin{array}{c}\text { Age } \\
\text { (Years) }\end{array}$ & Number of & \multicolumn{2}{|c|}{$\begin{array}{c}\text { In-group } \\
\text { percentage } \\
\text { animals }\end{array}$} & $\begin{array}{c}\text { Percentile share in total number } \\
\text { of seropositive animals }(\mathrm{n}=31)\end{array}$ \\
\hline $1-2$ & 50 & 11 & 22.0 & $(\%)$ \\
\hline $3-4$ & 56 & 12 & 21.4 & 35.5 \\
\hline $5+$ & 44 & 8 & 18.2 & 38.7 \\
Total & 150 & 31 & 20.7 & 25.8 \\
\hline
\end{tabular}

older were $22 \%(11 / 50), 21.4 \%(12 / 56)$, and $18.2 \%$ (8/44), respectively (Tab. 3 ). The differences detected between the age groups were statistically insignificant $(\mathrm{P}>0.05)$.

Dirofilariasis is caused by filarial nematodes belonging to the genus Dirofilaria (16). In regions where dirofilariasis is endemic in dogs, cats are also considered to be under risk of infection and most possibly carry the disease (10). In the present study, which was aimed at determining the seroprevalence of dirofilariasis in indoor cats with outdoor access in the Kars region, the prevalence of the disease was ascertained as $20.7 \%$. Although the prevalence of dirofilariasis in cats has not been investigated in Turkey before, studies are available indicating different prevalences for the disease in dogs. Accordingly, in serological research carried out in Sivas (2), Thrace (8), Elazı̆̆ (5), KarsIğdır (29), Iğdır (27) and Van (15), the prevalence of D. immitis in dogs has been reported to range between $2.9 \%$ and $40 \%$.

The prevalence of dirofilariosis detected in cats in the present study was observed to fall within the prevalence range reported in the above mentioned studies carried out on dogs in Turkey for D. immitis, but was lower than the rates reported for dogs in Kars-Iğdır (29) and Iğdır (27). The differences observed between the results of the present study and the indicated inves- 
tigations were attributed to differences in the species investigated, the regions, and the number of samples collected.

In research carried out on cats with PCR, the prevalence of $D$. repens was reported as $0.7 \%$ in Poland (3). Also in research carried out on dogs with PCR the prevalence of $D$. repens was reported as $38.3 \%$ (3) and $25.8 \%$ (9). Furthermore, the prevalence of $D$. immitis antibody-positive in cats has been reported to range between $0.54 \%$ and $24.9 \%(7,21,22,25)$.

Montoya-Alonso et al. (24) reported that sex is influential on the prevalence of $D$. immitis in cats $(\mathrm{P}<0.001)$ and in this study the prevalence of the disease is higher in male cats than females. On the other hand, some other reports suggest that sex has no significance for the prevalence of the disease, yet nevertheless indicate a higher prevalence in male cats $(17,23)$. The present study also demonstrated that sex has no significance for the prevalence of dirofilariasis in cats. In contrast, Magi et al. (22) reported that the prevalence of $D$. immitis was insignificant and higher in female cats in comparison to male cats. Our study is in agreement with results of the Magi et al. (22).

There are several reports in the literature indicating that age has no statistically significant effect on the prevalence of disease in cats $(23,24)$ and $\operatorname{dogs}(2,29)$. Similar to these reports, the present study revealed no relation between the age of the animals and the prevalence of the disease. On the other hand, the prevalence of the D. immitis has been reported to significantly increase with advanced age in cats (17) and in dogs (5). Differently, although statistically insignificant, Magi et al. (22) reported a higher prevalence in 1 to 2 year old cats, compared to older cats, which is in agreement with the results of the our study.

In conclusion, the present study is important in that it is the first epidemiological report on the prevalence of dirofilariasis in cats from the Kars province and Turkey. The results of the present study have revealed a dirofilariasis seroprevalence of $20.7 \%$ in cats in the study area. In view of cats being under risk of infection in regions, where the disease is endemic in dogs, it was concluded that similar studies need to be conducted in cats in other regions of Turkey. Furthermore, the highest seropositivity rate having been detected in the centre of the Kars province, it was also concluded that cats in the city centre were under particularly high risk of infection, which requires prophylactic measures.

\section{References}

1. Alho A. M., Landum M., Ferreira C., Meireles J., Gonçalves L., de Carvalho L. M., Belo S.: Prevalence and seasonal variations of canine dirofilariosis in Portugal. Vet. Parasitol. 2014, 206, 99-105.

2. Ataş A. D., Altay K., Alim A., Özkan E.: Survey of Dirofilaria immitis in dogs from Sivas Province in the Central Anatolia Region of Turkey. Turk J. Vet. Anim. Sci. 2018, 42, 130-134

3. Bajer A., Rodo A., Mierzejewska E. J., Tolkacz K., Welc-Faleciak R.: The prevalence of Dirofilaria repens in cats, healthy dogs and dogs with concurrent babesiosis in an expansion zone in central Europe. BMC Vet. Res. 2016, 12 , 183.
4. Baker C. F., Tielemans E., Pollmeier M. G., McCall J. W., McCall S. D., Irwin J., Chester S. T., Carithers D. S., Rosentel J. K.: Efficacy of a single dose of a novel topical combination product containing eprinomectin to prevent heartworm infection in cats. Vet. Parasitol. 2014, 202, 49-53.

5. Balıkçı E., Sevgili M.: Elazı̆̆ ve çevresindeki köpeklerde Dirofilaria immitis'in seroprevalansı. FÜ Sağlık Bil. Derg. 2005, 19, 103-106.

6. Browne L. E., Carter T. D., Levy K. J., Snyder P. S., Johnson C. M.: Pulmonary arterial disease in cats seropositive for Dirofilaria immitis but lacking adult heartworms in the heart and lungs. Am. J. Vet. Res. 2005, 66, 1544-1549.

7. Carleton R. E., Tolbert M. K.: Prevalence of Dirofilaria immitis and gastrointestinal helminths in cats euthanized at animal control agencies in northwest Georgia. Vet. Parasitol. 2004, 119, 319-326.

8. Çetinkaya H., Akyazı I., Özkurt M., Matur E.: The serologic and molecular prevalence of heartworm disease in shelter dogs in the Thrace Region of Turkey. Kafkas Univ. Vet. Fak. Derg. 2016, 22, 751-755.

9. Demiaszkiewicz A. W., Polańczyk G., Osińska B., Pyziel A. M., Kuligowska I., Lachowicz J., Sikorski A.: The prevalence and distribution of Dirofilaria repens in dogs in the Mazovian Province of central-eastern Poland. Ann. Agric. Environ. Med. 2014, 21, 701-704.

10. Dunn K. F., Levy J. K., Colby K. N., Michaud R. I.: Diagnostic, treatment, and prevention protocols for feline heartworm infection in animal sheltering agencies. Vet. Parasitol. 2011, 176, 342-349.

11. Erkılıç E. E., Mor N., Babür C., Kırmızıgül A. H., Beyhan Y. E.: The seroprevalence of Toxoplasma gondii in cats from the Kars Region, Turkey. Israel J. Vet. Med. 2016, 71, 31-35.

12. Fernandez C., Chikweto A., Mofya S., Lanum L., Flynn P., Burnett J. P. Doherty D., Sharma R. N.: A serological study of Dirofilaria immitis in feral cats in Grenada, West Indies. J. Helminthol. 2010, 84, 390-393.

13. Genchi C., Kramer L. H., Rivasi F.: Dirofilarial infections in Europe. Vector Borne Zoonotic Dis. 2011, 11, 1307-1317.

14. Genchi M., Pengo G., Genchi C.: Efficacy of moxidectin microsphere sustained release formulation for the prevention of subcutaneous filarial (Dirofilaria repens) infection in dogs. Vet. Parasitol. 2010, 170, 167-169.

15. Göz Y., Koltas S., Altug N., Demirkazık M., Yüksek N., Agaoglu Z.: Van yöresi köpeklerinde Dirofilaria immitis'in seroprevalans1. YYÜ Vet. Fak. Derg. 2007 $18,5-8$

16. Gunathilaka N., Siriwardana S., Wijesooriya L., Gunaratne G., Perera N.: Subcutaneous dirofilariasis caused by Dirofilaria (Nochtiella) repens in Sri Lanka: A potential risk of transmitting human dirofilariasis. SAGE Open Med. Case Rep. 2017, 5, 1-4

17. Hou H., Cao L., Ren W., Wang D., Ding H., You J., Yao X., Dong H., Guo Y., Yuan S., Zhang X., Gong P.: Seroprevalence of Dirofilaria immitis in cats from Liaoning Province, Northeastern China. Korean J. Parasitol. 2017, 55, 673-677.

18. Kars Regional Directorate of Meteorology, Data date: 18.03.2019

19. Kramer L., Genchi C.: Feline heartworm infection: serological survey of asymptomatic cats living in northern Italy. Vet. Parasitol. 2002, 104, 43-50.

20. Litster A. L., Atwell R. B.: Feline heartworm disease: a clinical review. J. Feline Med. Surg. 2008, 10, 137-144.

21. Lu T. L., Wong J. Y., Tan T. L., Hung Y. W.: Prevalence and epidemiology of canine and feline heartworm infection in Taiwan. Parasit. Vectors 2017, 10, 484.

22. Magi M., Prati M. C., Sebastiani B., Bandecchi P., Guberti V.: Seroprevalence of feline heartworm disease in Tuscany. Vet. Rec. 2002, 150, 415-416.

23. Maia C., Ramos C., Coimbra M., Cardoso L., Campino L.: Prevalence of Dirofilaria immitis antigen and antibodies to Leishmania infantum in cats from southern Portugal. Parasitol. Int. 2015, 64, 154-156.

24. Montoya-Alonso J. A., Carretón E., García-Guasch L., Expósito J., Armario B. Morchón R., Simón F.: First epidemiological report of feline heartworm infection in the Barcelona metropolitan area (Spain). Parasit. Vectors 2014, 7, 506.

25. Omar O. I., Elamin E. A., Omer S. A., Alagaili A. N., Mohammed O. B. Seroprevalence of Dirofilaria immitis in dogs and cats in Riyadh City, Saudi Arabia. Trop. Biomed. 2018, 35, 531-540.

26. Öncel T., Vural G.: Seroprevalence of Dirofilaria immitis in stray dogs in İstanbul and İzmir. Turk. J. Vet. Anim. Sci. 2005, 29, 785-789.

27. Sarı B., Taşçı G. T., Kılıç Y.: Seroprevalance of Dirofilaria immitis, Ehrlichia canis and Borrelia burgdorferi in dogs in Iğdır province, Turkey. Kafkas Univ. Vet. Fak. Derg. 2013, 19, 735-739.

28. Simón F., Siles-Lucas M., Morchón R., González-Miguel J., Mellado I., Carretón E., Montoya-Alonso J. A.: Human and animal dirofilariasis: The emergence of a zoonotic mosaic. Clin. Microbiol. Rev. 2012, 25, 507-544.

29. Taşçı G. T., Kılıç Y.: The prevalance of Dirofilaria immitis (leidy, 1856) in dogs and investigations on potential vector mosquito species in Kars and Iğdır. Kafkas Univ. Vet. Fak. Derg. 2012, 18 (Suppl-A), A29-A34.

30. Vieira L., Silvestre-Ferreira A. C., Fontes-Sousa A. P., Balreira A. C., Morchón R. Carretón E., Vilhena H., Simón F., Montoya-Alonso J. A.: Seroprevalence of heartworm (Dirofilaria immitis) in feline and canine hosts from central and northern Portugal. J. Helminthol. 2015, 89, 625-629.

Corresponding author: Ass. Prof. Dr. Ekin Emre ERKILIÇ, Department of Internal Medicine, Faculty of Veterinary Medicine, University of Kafkas, 36300, Kars, Turkey; e-mail: ekin_emre_24@hotmail.com 